\title{
The Efficiency Measurement of National Board of Zakat in West Java
}

\section{Aas Nurasyiah, Rida Rosida, and Firmansyah}

Department of Islamic Economics and Finance, Universitas Pendidikan Indonesia Jl. Dr. Setiabudhi No. 229 Kota Bandung

\section{Abstract}

This study aims to determine and measure the efficiency of BAZNAS regency/city in West Java. The method used in this study is descriptive-comparative. The population of this study is BAZNAS regency/city in West Java province with a total sample of eleven regency/city in West Java during nine year (2010-2018) period. The data was analyzed using Data Envelopment Analysis (DEA). The results indicated that there are 3 Decision Making Unit (DMU) that are efficient (100\%) and inefficiency as much as 53 Decision Making Unit (DMU). Bekasi City and Kuningan Regency are two zakat institutions that are capable of achieving full efficiency. This means that the majority of

Corresponding Author:

Aas Nurasyiah

asnur.fna@upi.edu

Received: 10 February 2019

Accepted: 14 March 2019

Published: 28 March 2019

Publishing services provided by

Knowledge E

(c) Aas Nurasyiah et al. This

article is distributed under the

terms of the Creative Commons

Attribution License, which

permits unrestricted use and

redistribution provided that the

original author and source are

credited.

Selection and Peer-review under the responsibility of the ICIEBP Conference Committee. Baznas regency/city in West Java still have not achieved efficiency. Insights from this research to improve the efficiency of zakat institutions, it must increase the input (zakat collection) and the operational professionalism of zakat institutions.

Keywords: Efficiency, National Board of Zakat, Data Envelopment Analysis

\section{Introduction}

The unachieved of zakat potential in Indonesia is due to the dissatisfaction of muzakki in using BAZNAS services as a means of distributing their assets, giving rise to a behavior in which $44 \%$ of muzakki (the party who are obliged to pay zakat) choose to distribute their zakat individually (Uzaifah, 2007).

The increase of zakat collection in the period of 13 years amounted to 5310.15 percent. In 2002 to 2015, the growth in the increase in the collection of zakat, infaq and alms (ZIS) funds reached an average of 39.28 percent. This indicates that there is a high increase in public awareness to pay zakat through official zakat institutions. The high gap between potential and realization of ZIS collection is considered reasonable because of the low level of public trust and not all zakat institutions in Indonesia have transparent and periodically audited financial statements. This issues has an impact on the weakening of public trust, even if it is a fairly credible institution or legal zakat institution (Mintarti, 2011). 
In addition, this proves that there are inefficiencies in zakat institutions. Inefficiency of zakat institution in Indonesia in collecting and distributing zakat occur for several reasons, such as the regulation of zakat which is not required by law, from the viewpoint of muzakki still exist that distribute zakat directly to mustahik or through an unofficial zakat institution and public confidence to the zakat institution is still low.

According to the PIRAC survey, the level of public trust in zakat institutions in 2004 was only 15\% (Abidin, 2008). In addition, Zamil \& Rahman (2006) stated that not only in Indonesia, but in Malaysia which is the driving factor for the high participation in paying zakat are facility, transparency and efficiency of the zakat institution in the collection and distribution.

National Board of Zakat (BAZNAS) as a government zakat institution only manages 50 billion rupiah of funds, far below the private zakat institutions which mostly target the corporate sector.

TABLE 1: Total of Managed Zakat Funds Based on Zakat Institutions.

\begin{tabular}{l|c|}
\hline Institution & $\begin{array}{c}\text { Managed Fund } \\
\text { (IDR Billion) }\end{array}$ \\
\hline Dompet Dhuafa & 202 \\
\hline Rumah Zakat & 146 \\
\hline PKPU & 107 \\
\hline YBM BRI & 57 \\
\hline BAZNAS & 50 \\
\hline Lazis Nahdlatul Ulama & 0,6 \\
\hline Source: Tempo (2014) & \\
\hline
\end{tabular}

Based on Table 1, the performance of zakat institutions, both government and private institution, becomes an issue that needs to be investigated. Thus, the most important thing is how zakat institutions can manage their funds so that they can achieve optimal levels of efficiency (Noor \& et al., 2012).

Based on the problems mentioned above, some of the most important indications and need to be solved is the evaluation of the performance of zakat institutions with a focus on discussion on the level of efficiency. To evaluate the performance of an institution in terms of its efficiency, it can use the Data Envelopment Analysis (DEA) method.

According to Farrell, efficiency in a company is related to how to produce a maximum level of output with a certain number of inputs (Firdaus \& Hosen, 2013). Generally, 
efficciency is the ability of a business unit to reach the target by using the minimum available resources (Martić, Novaković, \& \& Baggia, 2009).

Islam has its views regarding to concept of efficiency based on QS. Al-Israa: 26-27. Production efficiency in Islam can be done with two approaches. First by minimizing costs, it can be done by reducing the total cost but the output of the product produced remains the same. Then the second approach is the optimization of production without any increase or change in total cost (Karim, 2015).

Research on efficiency at the zakat institution has been carried out by several researchers. Including by Wahab (2012) and (2013), Noor (2012) and (2012) and also been examined by Ahmad (2014), but all of the research was conducted in Malaysia. While in Indonesia, the efficiency research using the Data Envelopment Analysis (DEA) method on zakat institutions still few. The previous research as reference in measuring the efficiency in zakat institutions is done by Parisi (2017) as the first researcher in Indonesia relating to efficiency in zakat institution and Wahab \& Raman (2012) who examined the efficiency of zakat institutions in Malaysia.

Previous research conducted by Cahyono (2015) on the efficiency of the performance of the National Board of Zakat (BAZNAS) in Indonesia using the Data Envelopment Analysis (DEA) approach, which measures the ratio of the ratio between output and input compared between the years studied. The results indicate that from the year period examined by the National Board of Zakat (BAZNAS) fluctuated in the efficiency of its performance. Then Rusydiana \& Farisi (2016) examined the efficiency of BAZNAS, PKPU, and Rumah Zakat (RZ) with varying years. The results of this study were 12 Decision Making Unit (DMU) that were perfectly efficient (100\%) and inefficient as many as 6 DMUs. The most inefficient zakat institution is Rumah Zakat (2013), and PKPU is able to maintain its efficiency level gradually from 2007 to 2014 (except 2013) when compared to other zakat institution.

Thus this study aims to determine and measure the efficiency of BAZNAS regency/city in West Java during the period $2010-2018$.

\section{Literature Review}

\subsection{The concept of efficiency theory}

The concept of efficiency comes from the micro-economic concept, namely the producer theory. This theory tries to maximize profits or minimize costs from the producer's perspective. In the producer theory there is a production frontier curve that 
describes the relationship between input and output of the production process. This curve represents the maximum level of output for each use of input that represents the use of technology from a company or industry (Ascarya \& \& Yumanta, Analisis Efisiensi Perbankan Syariah di Indonesia dengan Data Envelopment Analysis"., 2006).

Ascarya et al. (2008) explained that the forntier approach is superior because the use of program techniques or statistics that eliminate the influence of differences in input prices and other exogenous factors in influencing the performance to be observed. The forntier approach is divided into two types, there are parametric and non-parametric.

The Stochastic Frontier Approuch (SFA) approach, Thick Frontier Approuch (TFA) and Distribution Free Approuch (DFA) are paremetric approaches, while non-parametric approaches include Data Envelopment Approuch (DEA) and Free Disposable Hull (FDH) (Syakir, 2004). Hadad et al. (2003) added that the parametric and non-parametric approaches would essentially obtain relatively the same results, if the samples analyzed were the same unit and used the same production process.

According to Farrell (1957) the concept of efficiency of the company consists of two components, namely technical efficiency and allocative efficiency. Technical efficiency reflects the ability of the company to produce output with a number of available inputs. Whereas allocative efficiency reflects the company's ability to optimize its use of inputs, with the price structure and production technology. These two sizes are then combined into economic efficiency (economic efficiency).

Efficiency is defined as the ratio between output and input. There are three factors that cause efficiency: (1) the same input can produce greater output, (2) smaller inputs can produce the same output, and (3) larger inputs can produce more output with a percentage large than the amount of additional input (Hidayat, 2014). Thus, efficiency in the zakat institution is very important. According to Noor (2012), the performance and measurement systems must be developed in zakat institutions. This is an effort to oversee the accountability of zakat management institutions.

\subsection{The concept of efficiency theory in Islam}

Efficiency theory is closely related to production theory which involves input variables to produce output. One of the theories on the efficiency in Islamic perspective is explained by Karim (2015). According to him, production efficiency in Islam can be done through two approaches. The first approach is production efficiency based on minimal costs. Cost minimization by producers can be done by reducing the total cost or production 
costs, both fixed costs and variable costs in order to minimize the average cost of production.

As for the second approach, production efficiency is carried out with optimal production. Maximizing output is done by producers by making maximum use of the production factors they have, so that producers can maximize the amount of output produced as effectively and efficiently as possible in their production activities. The meaning of efficiency in a simple way can be interpreted as doing something in a good and appropriate way and not excessive. In Islamic economic perspective views that the concept of efficiency is in line with one of the goals of maqashid sharia, namely the maintenance of charity

The purpose of efficiency is to achieve optimal profits with the results of increasing quality and quantity. In Islam, the term of efficiency is currently described by Oemar Chapra (2000) as a comparison between useful output in the presence of input. Not just a comparison between input and output. That is, the concept of efficiency is always in tandem with the utilization of existing resources (inputs) to obtain useful results (output) (Chapra, 2000), without being excessive and also having an impact on waste.

\subsection{Efficiency approach to Zakat management organizations}

According to Akbar (2009), Zakat Institution (OPZ) is an organizations that act as amil zakat. In carrying out its duties, zakat institutions need large operational funds, ranging from employee (amil) salaries), socialization costs, and other operational costs. On the basis of this condition, an effort is needed to streamline the operational costs of the Zakat Institution (OPZ) in accordance with the level of needs and importance. So that the costs incurred are in accordance with the needs of the Zakat Institution (OPZ). Thus the assets of zakat can be maximized in order to achieve the goal of zakat, which is to improve the welfare of the poor people and reduce poverty.

\section{Methodology}

The research method used is descriptive-comparative in order to compare the level of efficiency in National Board of Zakat (BAZNAS) regency/city in West Java period 20102018. To measure and analyze the efficiency of BAZNAS, the data was analyze using the Data Envelopment Analysis (DEA).

The steps taken to analyze efficiency are as follows: 
1. Searching and collecting the input and output data taken from financial overview of the zakat institution financial statements concerned with samples in the period 2010-2018.

2. Calculating the efficiency values at zakat institutions using software MAX DEA 6.1 and DEAP 2.1.

3. Determining the target of efficiency improvement based on the calculation of DEA.

4. Interpreting the results obtained.

The population of this study is BAZNAS regency/city in West Java province during the 2010-2018 period. While the sampling method used is purposive sampling with quota sampling approach with criteria data are available in BAZNAS regency/city financial statement. Thus the sample that will be examined are as follows:

TABLE 2: BAZNAS Regency/ City in West Java.

\begin{tabular}{l|l|l|l} 
No & BAZNAS & No & BAZNAS \\
1 & West Java & 7 & Banjar Regency \\
2 & Karawang Regency & 8 & Kuningan Regency \\
3 & Ciamis Regency & 9 & Subang Regency \\
4 & Cirebon City & 10 & Cirebon Regency \\
5 & Bekasi City & 11 & Purwakarta Regency \\
6 & Cimahi City & & \\
Source: BAZNAS West Java Province (2018)
\end{tabular}

The type of data used in this study is quantitative in the form of numbers, secondary and time series data. In addition, the source of data in this study came from BAZNAS's financial statements period 2010 - 2018. The data is obtained from the official BAZNAS website or through direct visits to the office of BAZNAS regency/city in order to request BAZNAS financial statements.

\section{Result}

Based on the results of the study, it can be seen that the general description of the characteristics of efficiency is divided into two parts, namely efficient and inefficient. Inefficient scores are categorized as increasing and decreasing.

Moreover by using an input approach, increasing can be interpreted as a variable of operational costs used can be added again so that it can achieve optimal levels of collection and distribution. 
In addition, decreasing can be interpreted as the value of efficiency that is already excessive. Therefore these inefficiencies are needed to withstand operational costs or even save operational costs. So that the collection and distribution can develop well.

Furthermore, constant conditions in the input approach can be interpreted as sufficient operational costs. No need to save or increase. Thus, zakat institutions that experience this condition only need to focus on how to improve the collection nd distribution of zakat funds.

TABLE 3: Efficiency Score of National Board of Zakat Regency/City in West Javaa.

\begin{tabular}{|c|c|c|c|}
\hline No & Zakat Institution & Efficiency Score & RTS Input \\
\hline 1 & 2018-Bekasi City & 1 & Constant \\
\hline \multirow[t]{2}{*}{2} & 2015-Kuningan Regency & 1 & Decreasing \\
\hline & 2017-Kuningan Regency & 1 & Decreasing \\
\hline 4 & 2017-Ciamis Regency & 0,957 & Decreasing \\
\hline 5 & 2014-Kuningan Regency & 0,954 & Decreasing \\
\hline 6 & 2015-West Java & 0,950 & Decreasing \\
\hline 7 & 2016-Kuningan Regency & 0,909 & Decreasing \\
\hline 8 & 2013-Kuningan Regency & 0,866 & Decreasing \\
\hline 9 & 2016-Ciamis Regency & 0,848 & Decreasing \\
\hline 10 & 2016-Banjar Regency & 0,832 & Constant \\
\hline 11 & 2016-West Java & 0,801 & Decreasing \\
\hline 12 & 2012-Kuningan Regency & 0,777 & Decreasing \\
\hline 13 & 2011-Kuningan Regency & 0,736 & Decreasing \\
\hline 14 & 2017-Bekasi City & 0,717 & Decreasing \\
\hline 15 & 2010-Kuningan Regency & 0,652 & Decreasing \\
\hline 16 & 2017-Banjar Regency & 0,514 & Constant \\
\hline 17 & 2016-Cirebon Regency & 0,437 & Decreasing \\
\hline 18 & 2013-Cirebon Regency & 0,436 & Decreasing \\
\hline 19 & 2014-Cirebon Regency & 0,429 & Decreasing \\
\hline 20 & 2015-Cirebon Regency & 0,419 & Decreasing \\
\hline 21 & 2012-Cirebon Regency & 0,415 & Decreasing \\
\hline 22 & 2011-Cirebon Regency & 0,388 & Decreasing \\
\hline 23 & 2018-Banjar Regency & 0,337 & Constant \\
\hline 24 & 2016-Bekasi City & 0,311 & Decreasing \\
\hline 25 & 2017-Cirebon City & 0,305 & Decreasing \\
\hline 26 & 2016-Cirebon City & 0,212 & Decreasing \\
\hline 27 & 2015-Cirebon City & 0,211 & Decreasing \\
\hline 28 & 2015-Banjar Regency & 0,210 & Constant \\
\hline 29 & 2013-Banjar Regency & 0,209 & Constant \\
\hline 30 & 2014-Banjar Regency & 0,201 & Constant \\
\hline
\end{tabular}




\begin{tabular}{|c|c|c|c|}
\hline No & Zakat Institution & Efficiency Score & RTS Input \\
\hline 31 & 2014-Cirebon City & 0,198 & Decreasing \\
\hline 32 & 2013-Cirebon City & 0,191 & Decreasing \\
\hline 33 & 2017-Purwakarta Regency & 0,154 & Decreasing \\
\hline 34 & 2017-Karawang Regency & 0,150 & Constant \\
\hline 35 & 2018-Karawang Regency & 0,149 & Decreasing \\
\hline 36 & 2011-Banjar Regency & 0,143 & Constant \\
\hline 37 & 2012-Banjar Regency & 0,143 & Constant \\
\hline 38 & 2015-Purwakarta Regency & 0,139 & Decreasing \\
\hline 39 & 2016-Purwakarta Regency & 0,130 & Decreasing \\
\hline 40 & 2014-Subang Regency & 0,100 & Decreasing \\
\hline 41 & 2011-West Java & 0,088 & Decreasing \\
\hline 42 & 2017-Cimahi City & 0,086 & Decreasing \\
\hline 43 & 2016-Subang Regency & 0,083 & Decreasing \\
\hline 44 & 2017-Subang Regency & 0,081 & Decreasing \\
\hline 45 & 2016-Cimahi City & 0,079 & Decreasing \\
\hline 46 & 2010-Banjar Regency & 0,075 & Constant \\
\hline 47 & 2013-Subang Regency & 0,071 & Decreasing \\
\hline 48 & 2014-Cimahi City & 0,065 & Decreasing \\
\hline 49 & 2015-Cimahi City & 0,064 & Decreasing \\
\hline 50 & 2015-Subang Regency & 0,061 & Decreasing \\
\hline 51 & 2014-West Java & 0,061 & Decreasing \\
\hline 52 & 2012-West Java & 0,053 & Decreasing \\
\hline 53 & 2012-Subang Regency & 0,053 & Decreasing \\
\hline 54 & 2011-Subang Regency & 0,048 & Decreasing \\
\hline 55 & 2013-West Java & 0,039 & Decreasing \\
\hline 56 & 2010-Subang Regency & 0,019 & Constant \\
\hline
\end{tabular}

Based on the table 3, National Board of Zakat (Baznas) Kuningan Regency in 2015 and 2017 still decreasing even though it is included in fully efficient. This case indicated that National Board of Zakat (Baznas) Kuningan Regency can be improved.

Then, we know that only $5.36 \%$ of baznas in West Java has experiences efficiency. This means that almost all of Baznas in West Java experience inefficiencies. But this is not a benchmark that Baznas in West Java has very low value for efficiency. Even though at the level of inefficiency, Baznas in West Java has the potential to achieve full efficiency in the future. This is because of the average inefficiency occurs in the years (2010-2014). 
In addition, there are 3 National Board of Zakat (Baznas) as Decision Making Unit (DMU) which were mostly referred regarding of its full efficient score, namely Baznas in Bekasi City, Kuningan District in 2015 and 2017. The result can be seen on the table below:

TABLE 4: Efficiency and Inefficiency Score.

\begin{tabular}{l|c|c|}
\hline Zakat Institution & Efficiency Score & $\begin{array}{c}\text { Times of } \\
\text { Benchmark }\end{array}$ \\
\hline 2018-Bekasi City & Fully Efficient & 48 \\
\hline 2015-Kuningan Regency & Fully Efficient & 37 \\
\hline 2017-Kuningan Regency & Fully Efficient & 5 \\
\hline $\begin{array}{l}\text { All Zakat Institution except 3 at } \\
\text { above }\end{array}$ & Inefficient & 0 \\
\hline Source: Research Results (2018) & & \\
\hline
\end{tabular}

Furthermore factors that cause inefficiencies are used as a basis for how in order to overcome inefficiencies. The cause of determine inefficiency can be seen on the result of software max dea at column slack movement and proportionate movement must not be equal zero $(\neq 0)$ as follows:

TABLE 5: Factors That Cause Inefficiency.

\begin{tabular}{l|l|l|l|}
\hline Variable & $\begin{array}{c}\text { Slack or (/) } \\
\text { Proportionate } \\
\text { Movement }\end{array}$ & Description \\
\hline Input & Operating Expenses & $0 / 5$ & $\begin{array}{l}\text { Total of input score } \leq \text { output score } \\
\text { This means that the input variable is } \\
\text { not the cause of inefficiency }\end{array}$ \\
\hline Output & Collection Funds & $34 / 53$ & $\begin{array}{l}\text { Total of output score } \geq \text { input score. } \\
\text { This means that the output variable } \\
\text { is the caouse of inefficiency }\end{array}$ \\
\hline Source: Research Results (2018) & $19 / 53$ & \\
\hline
\end{tabular}

Based on table 5, it can be concluded that the causes of inefficiency is output factors, while input factors do not significantly contribute to the causes of inefficiency.

The inefficiencies in output factors occur due to the collection of zakat which is still low but the distribution is better. This is a new finding, where many studies explain that the cause of the inefficiency of zakat management organizations is due to the low of distribution. 
To find out the source of inefficiency form Baznas in this study, it can be seen through the total potential improvement in the table 6 . It works when it has been fully implemented by Baznas.

TABLE 6: Potential Improvement for Increasing Efficiency of BAZNAS Output Orientation.

\begin{tabular}{|l|c|c|c|}
\hline Zakat Institution & \multicolumn{3}{|c|}{ Average (\%) } \\
\hline 2010-2018 Banjar Regency & X1 & Y1 & Y2 \\
\hline 2010-2017 Kuningan Regency & 0 & 77 & 74 \\
\hline 2010-2017 Subang Regency & -1 & 15 & 14 \\
\hline 2011-2016 West Java & 0 & 94 & 94 \\
\hline 2011-2016 Cirebon Regency & -18 & 68 & 76 \\
\hline 2013-2017 Cirebon City & 0 & 61 & 58 \\
\hline 2014-2017 Cimahi City & 0 & 79 & 78 \\
\hline 2015-2017 Purwakarta Regency & 0 & 89 & 86 \\
\hline 2016-2017 Ciamis Regency & -54 & 9,5 & 20 \\
\hline 2016-2018 Bekasi City & 0 & 32 & 34 \\
\hline 2017-2018 Karawang Regency & 0 & 86 & 85 \\
\hline Mean & -7 & 64 & 65 \\
\hline Source: Research Results (2018) & & & \\
\hline
\end{tabular}

Based on Table 6 with an output orientation approach, the main source of inefficiency in BAZNAS are as follows:

1. The average operational cost used by National Board of Zakat (Baznas) in West Java is smaller than the output variable. This means that the reduction or retention of operational costs is not a priority.

2. The average increase in zakat collection that can be achieved by Baznas in West Java in order to not experience inefficiencies in the future by $64 \%$.

3. The average value of the maximum zakat distribution can be achieved by National Board of Zakat (Baznas) in West Java is 65\%.

4. Baznas with the recommendation to increase the highest collection and distribution are Subang Regency, Cimahi City, Purwakarta Regency and Karawang Regency.

5. Baznas with the recommendation to reduce or withstand operational costs are Ciamis regency and Baznas West Java. 
6. In addition, there are two best zakat institutions so that there is no need to increase output or reduce input significantly namely Baznas Bekasi City and Baznas Kuningan Regency.

The results of this study are not absolute, the addition of zakat institutions or periods can change the results.

\section{Conclusion}

There are 3 Decision Making Unit (DMU) that are efficient (100\%) and inefficiency as much as 53 Decision Making Unit (DMU). Bekasi City and Kuningan Regency are two zakat institutions that are capable of achieving full efficiency. This means that the majority of Baznas regency/city in West Java still have not achieved efficiency.

In general, the main cause of inefficiency factor of Zakat Institution from 2010 to 2018 due to the lack of zakat fund collected by Zakat Institution. Lack of total collection leads to a lack of limited distribution and operational usefulness. If the collection can be enlarged, it will make Baznas in West Java are able to give a socio-economic impact on the people in West Java. Therefore the role of the government in assisting the collection of baznas are highly needed.

National Board of Zakat that have not been able to reach full efficiency levels can make improvements by focusing on increasing the collection and distribution of zakat funds. With the exception of Baznas Ciamis Regency and West Java, which need to withstand operational costs.

\section{References}

[1] Abidin, H. (2008). Potensi dan Ironi Zakat. Jakarta: PIRAC.

[2] Ahmad, I., \& Ma;in, M. (2014). The Efficiency of Zakat Collection and Distribution: Evidance from Two Stage Analysis. Journal of Economic Cooperation and Development, 35, 3 (2014) , 133-170.

[3] Akbar, N. (2009). Analisis Efisiensi Organisasi Pengelola Zakat Nasional dengan Pendekatan Data Envelopment Analysis. Tazkia Islamic Finance and Business Review. Vol. 4 No. 2.

[4] Ascarya , \& \& Yumanta, D. (2006). Analisis Efisiensi Perbankan Syariah di Indonesia dengan Data Envelopment Analysis". TAZKIA Islamic Finance and Business Review, Vol.1, No.2, pp. 1-32. 
[5] Ascarya, Diana, Y., \& Guruh, S. (2008). Analisis Efisiensi Perbankan Konvensional dan Perbankan Syariah di Indonesia dengan Data Envelopment Analysis (DEA) . Paper dalam Buku Current Issues Lembaga Keuangan Syariah Tahun 2009, TIM IAEI, Jakarta: Kencana.

[6] Cahyono, F. (2015). Efficiency of BAZNAS (Indonesian National Zakat Amil Agency) Performance. Proceedings of Sydney International Bussiness Research Conference . Sydney (AUS).

[7] Chapra, M. O. (2000). Islam dan Tantangan Ekonomi. Jakarta: Gema Insani Press.

[8] Farrell, M. (1957). The Measurement of Productive Efficiency. Journal of The Royal Statistical Society, 120, p.253-281.

[9] Firdaus, M., \& Hosen, M. (2013). Efisiensi Bank Umum Syariah Menggunakan Pendekatan Two-Stage Data Envelopment Analysis. Buletin.

[10] Hadad, M., Santoso, W., llyas , D., \& Mardanugraha, E. (2003). Analisis Efisiensi Industri Perbankan Indonesia: Penggunaan Metode Nonparametrik Data Envelopment Analysis (DEA). Jakarta : Direktorat Penelitian dan Pengaturan Perbankan. Bank Indonesia.

[11] Hidayat, R. (2014). Efisiensi Perbankan Syariah Teori dan Praktik. Bekasi.

[12] Karim, A. (2015). Ekonomi Mikro Islami Edisi Kelima. Jakarta: PT RajaGrafindo Persada.

[13] Martić, M., Novaković, M., \& \& Baggia, A. (2009). Data envelopment analysis - basic models and their utilization. Organizacija, Research Papers, 42,, 37-43.

[14] Mintarti, N. (2011, April 12). Membangun Kepercayaan Publik dan Kapasitas Pengelolaan Zakat Di Indonesia. Diambil kembali dari http://www.imz.or.id: http://www.imz.or.id/new/article/773/membangun-kepercayaan-publik-dankapasitas-pengelolaan-zakat-di-indonesia/?lang=id

[15] Noor, A. H., \& al., e. (2012). Efficiency of Islamic Intitution: Empirical Evidance of Zakat Organization Performance in Malaysia. Journal of Economics, Business and Management, Vol 3 No. 2.

[16] Noor, A., \& et al. (2012). Assecing Performan of Nonprofit Organization: A Framework for Zakat Intitution . British Journal of Economics, Finance and Management Science, Vol. 5 (1).

[17] Parisi, S. A. (2017). Tingkat Efisiensi dan Produktivitas Lembaga Zakat di Indonesia. Esensi: Jurnal Bisnis dan Manajemen Volume 7 (1), 63-72.

[18] Rusydiana, A., \& Farisi, S. A. (2016). The Efficiency of Zakah Intitution Using Data Envelopment Analysis. Journal of Islamic Economic, Al-lqtishad, Vol. 8 (2), 213-226. 
[19] Srivastava, P. (1999). Size, Efficiency and Financial Reforms In Indian Banking. Working Paper No. 49. Indian Council For Research on International Economic Relation.

[20] Syakir, A. (2004). Mengukur Efisiensi Intermediasi Sebelas Bank Terbesar Indonesia Dengan Pendekatan Data Envelopment Analysi (DEA). Jurnal Bisnis Strategi. Vol.13. Hal. 126-139, Semarang.

[21] Tempo. (2014, 4 14). Tikungan Tajam Amil Zakat. Diambil kembali dari Tempo: https: //majalah.tempo.co/read/145150/tikungan-tajam-amil-zakat

[22] Uzaifah. (2007). Studi Deskriptif Prilaku Dosen Perguruan Tinggi Islam DIY dalam Membayar Zakat. La Riba Jurnal Ekonomi Islam, Vol. 1 No 1.

[23] Wahab, N., \& Rahman, A. (2012). Efficiency of Zakat Institutions in Malaysia: An Application of Data Envelopment Analysis. Journal of Economic Cooperation and Development, Vol. 33, No. 1, 2012, 95-112.

[24] Wahab, N., \& Rahman, A. (2012). Productivity Growth of Zakat intitutions in Malasia, an Aplication of Data Envelopment Analysis. Emerald Grup Publising Limited, Studies in Economics and Finance Vol. 29 No. 3, 2012, 197-210.

[25] Wahab, N., Rahman, A., \& Rahim , A. (2013). Determinants of Efficeiancy of Zakat Intituion in Malaysia: A Non-Parametric Approach. Asian Juornal of Business and Accounting 6 (2) 2013.

[26] Zamil, N. M., \& Rahman, A. A. (2006). Efficiency of Islamic and Conventional Commercial Banks in Malaysia: A Data Envelopment Analysis (DEA) Study. Malaysia: IIUM. 